DADDMNE
D I I A L L

UMR 225 IRD - Paris-Dauphine
Institut de recherche pour le développement

\title{
The Impact of MERCOSUR on Trade of Brazilian States
}

\section{Jean-Marc SIROEN}

Aycil YUCER 


\title{
THE IMPACT OF MERCOSUR ON TRADE OF BRAZILIAN STATES
}

\author{
Jean-Marc SIROEN \\ IRD, UMR DIAL \\ LEDa-Université Paris-Dauphine \\ Jean-Marc.Siroen@dauphine.fr \\ Aycil Yucer \\ LEDa, UMR DIAL-Université Paris-Dauphine \\ aycily@gmail.com
}

Document de travail UMR DIAL

Septembre 2011

\begin{abstract}
We consider the impact of MERCOSUR on trade among Brazilian states and on trade by Brazilian states with MERCOSUR and the rest of the world. We use a theoretically founded gravity model to shed light on MERCOSUR's possible creation and diversion effects as well as its "preference erosion" effect on trade among Brazilian states. Using data on interstate trade over a four-year period, including one year prior to the MERCOSUR period (1991), we deliver empirical evidence at state level with a focus on the impact of MERCOSUR which can vary across Brazilian regions. We show that MERCOSUR increased Brazilian states' trade with member countries, but had no effect on either interstate trade or Brazilian states' trade with third countries. The paper finds that MERCOSUR's impact varies across Brazilian regions and that the Northern region is relatively less well integrated into international trade. We use an estimation method dealing better with the traditional issue of zero trade values and heteroskedasticity than OLS does.
\end{abstract}

Keywords: Regional Trade Agreements; MERCOSUR; Gravity Model; Trade Diversion; Trade Creation; Preference Erosion.

\section{Résumé}

Le document décompose l'impact du MERCOSUR sur le commerce brésilien en distinguant les effets de l'accord sur les échanges entre les États brésiliens et de chaque État brésilien avec le MERCOSUR et le reste du monde. Nous utilisons un modèle de gravité théoriquement fondé pour mettre en évidence non seulement les éventuels effets de création et de détournement de commerce mais également un effet d'"érosion des préférences" quand on considère le Brésil comme un bloc commercial qui regrouperait les États. En utilisant les données sur le commerce interétatique sur une période de quatre ans, dont un an avant la période du MERCOSUR (1991), nous aboutissons à des résultats empiriques au niveau des 27 États brésiliens sur les impacts du MERCOSUR sur le commerce qui peuvent varier selon les régions du Brésil. Nous montrons que le MERCOSUR a permis d'augmenter le commerce des États avec les pays membres, sans effets importants sur le commerce interétatique ou avec les pays tiers. Nous confirmons que l'impact du MERCOSUR varie selon les régions du Brésil et que la région du Nord est relativement moins bien intégrée dans le commerce international. Nous utilisons une méthode d'estimation qui résout certains des problèmes des modèles de gravité comme les valeurs de commerce nulles et l’hétéroscédasticité trouvée en MCO.

Mots Clés : Accords commerciaux régionaux, MERCOSUR, Modèles de gravité, Détournement de commerce, Création de commerce, Érosion des préférences.

JEL Codes : F140, F150, R100, R500 


\section{Introduction}

Much like other Latin American and many developing countries, Brazil long promoted an "import substitution" strategy and kept its doors relatively closed to international trade, endeavoring to take advantage of its subcontinental status to promote domestic trade. Starting in the 1950s and throughout the military dictatorship (1964-1985), governments implemented protectionist and industrial policies to diversify the production structure seen as too highly concentrated in primary goods. This strategy was closely associated with regional development policies, managed at federal level, with infrastructure investment (e.g. the Trans-Amazonian Highway) and with policies to attract foreign capital in order to produce manufactured goods mainly for the Brazilian market (creation of the Manaus Free Trade Zone in 1967). However, the "Brazilian miracle" turned into an inflationary and over-indebted economy. The return to democracy strengthened the federal system by giving more rights to states and municipalities (Constitution of 1988) and, starting in the 1990s, the Real Plan opened the country up to international trade.

The previous Brazilian development strategy should have promoted specialization across Brazilian regions instead of a specialization at national level. However, the most recent trade openness strategy, albeit incomplete, should lead Brazil as a whole to become more specialized. This implies a substitution of imported goods for previously uncompetitive homemade products, which means that, in relative terms, each state should trade less with one another and more with foreign countries. We would then expect international trade openness to reduce interstate trade compared with foreign trade.

Although openness had a significant multilateral component with the reduction of applied MFN (Most-Favored Nation) tariffs, Brazilian trade openness went ahead within the regional MERCOSUR (Mercado Común del Sur) framework (Treaty of Asunción, 1991). However, unlike other Latin American countries (e.g. Chile, Mexico and Peru), Brazil has few preferential trade agreements. MERCOSUR is virtually the only regional or bilateral agreement Brazil has signed, which makes it easier to isolate its repercussions on Brazilian domestic and foreign trade.

Vinerian and post-Vinerian literature on the impact of customs unions on trade usually considers member countries to be a single, fully integrated entity and therefore ignores the effects of such agreements on domestic trade. The trade creation/diversion effect is supposed to be found only between member and third countries, not within countries. This is highly debatable for a country as fragmented as Brazil. We can consider pre-MERCOSUR Brazil to be a customs union between the 27 Brazilian states, diverting trade from other countries including the current MERCOSUR. We can then consider the Treaty of Asunción to be an enlargement to three neighboring countries (Argentina, Paraguay and Uruguay), expected to produce three different effects: first, a trade creation effect for Brazilian states, e.g. increasing trade between each Brazilian state and its new partners; secondly a diversion effect vis-à-vis third countries - the rest of the world - and, lastly, a "preference erosion" " effect due to the fact that "duty free" trade among Brazilian states is extended to MERCOSUR countries, leaving some uncompetitive Brazilian producers exposed to new foreign competition. It is precisely the distribution of this "preference erosion" effect across the country's different regions that is frequently ignored by the regional integration literature. Theoretically, the eviction of uncompetitive outputs is part of the trade creation effect, e.g. a welfare gain for Brazil due to a net consumer gain derived from a lower price for goods imported from other MERCOSUR countries. However the trade effects of MERCOSUR could be unevenly distributed across Brazilian states. The most competitive states might maintain their market share on Brazilian markets and increase their exports to MERCOSUR, while others may be faced with dwindling exports to other Brazilian states as they fail to increase their exports to MERCOSUR. For a country like Brazil, which suffers from strong regional inequalities and whose domestic market is highly fragmented, the impact of MERCOSUR will vary a great deal across the 27 states (26+Federal District).

The Treaty of Asunción should then generate relative growth in Brazilian states' trade with other MERCOSUR countries and a decrease with other Brazilian states (preference erosion effect) and the rest of the world (diversion effect). However, this outcome based on basic static theory could well overlook unexpected adaptation to globalization. Actually, one of the most challenging consequences of trade globalization is the acceleration of the

\footnotetext{
${ }^{1}$ Preference Erosion refers to erosion in the value of preferential access, where trade liberalization leads a decrease in prices on the market to which a country (Brazilian states) has been given preferential trading access.
} 
vertical specialization process and the international fragmentation of the "value chain"2. Once we consider Brazil as an aggregation of 27 states, which all have their specific comparative advantages, trade openness might have led to greater vertical specialization between Brazilian states, e.g. São Paulo processing of primary products exported from Minas Gerais or relocation of labor-intensive activities from "rich" states to poor states paying lower wages. Moreover, the small number of "ports" (air or sea) might also foster vertical specialization, for example, with the location of assembly work close to a port.

This context of relatively rapid Brazilian openness in 1990s and the availability of even just a few years of interstate trade data mean that we can look at the Brazilian states as trade entities arbitrating between domestic and foreign markets, the former comprising trade among Brazilian states and the latter with MERCOSUR and other countries.

The aim of this paper is to consider the effects of MERCOSUR on the direction of Brazilian trade. In the second section, we present the issue and the possible regionally different effects of MERCOSUR on Brazilian trade. In the third section, we present our empirical methodology, the basic specification for the gravity model we use and our data sources. The fourth section delivers empirical evidence for trade creation, trade diversion and preference erosion at state level. The fifth section focuses on the impact of MERCOSUR which can vary across Brazilian regions. We conclude in the last section.

\section{Previous Studies and a New Focus on the Issue}

Studies on interstate trade are nothing new, but the literature on the "border effect" gives new reasons to reconsider it. One of the most famous papers on the topic is McCallum's "home bias" (McCallum, 1995). In it, he estimates trade between Canadian provinces at 22 times expected trade between Canadian provinces and the U.S. The inclusion of control variables in the gravity model used, including the distance between regions and their size, enabled the author to attribute this huge "home bias" to a "border effect" as a large impediment to trade. Since this seminal work, the border effect has been confirmed, albeit less intense, by refined econometric methods that do a better job of dealing with the omitted variables bias and size heterogeneity, obviously important in the case of USCanadian trade (Helliwell, 1998; Wolf, 2000; Anderson \& van Wincoop, 2003; Balistreri \& Hillberry, 2007). Other empirical studies concern other countries like China (Poncet, 2003; 2005), Japan (Okubo, 2004) and the EU (Chen, 2004). However, there is a lack of domestic inter-regional trade data available to be able to estimate border effects for other countries and regions.

On the basis of available interstate trade data, some authors have quantified this domestic fragmentation compared with the level of Brazilian state integration into the world market. Hidalgo and Vergolino (1998) find that Brazilian interstate exports are 11.5 times higher than exports from Brazilian states to foreign countries (cross-section for 1991). However, the model is highly biased by the absence of country/state fixed effects to control for a heterogeneity bias and by the elimination of zero observations. Pooling the data for the four available years (1991, 1997, 1998 and 1999), Paz and Franco (2003) obtain border effect measurements that are sometimes implausible. Results are actually sensitive to different methods (inclusion of country/state fixed effects and treatment of zero observations). Using the same data for intra-state, interstate and international trade, Daumal \& Zignago (2010) focus on both the "home bias" and on Brazilian interstate integration compared with intra-state trade. After controlling for size, distance and heterogeneity (country/state fixed effects), they show that Brazilian states trade 38 times more with each other than with foreign countries. Leusin et al. (2009) and Silva et al. (2007) find very similar results for the same time period.

Brazil's relative fragmentation originates mainly in historically uneven and disjointed development across different Brazilian regions, hardly corrected by regional integration policies. It is seen in high domestic transport costs due to the lack of infrastructures and large inter-regional inequalities accompanied by differences in consumption preferences. Even though it swings cyclically between "recentralization" and "decentralization" periods, Brazil is a federal country with considerable state autonomy in terms of regulation and fiscal policy. For example, the Brazilian equivalent of VAT (ICMS) is collected at state level, which introduces distortions in interstate trade and probably contributes to the interstate border effect (see Brami and Siroen, 2007). At the beginning of the 1990s, Brazil was not only an economy relatively closed to trade with foreign countries, but each state was more (Northern states) or less

${ }^{2}$ There is a very large body of literature on this process and its consequences, including on the global trade slump in 2008-2009. For example, Hummels et al .(2001), Yi (2003; 2009) and Freund (2009). 
(Southern states) closed to trade with other states. Daumal \& Zignago (2010) point out that, despite significant progress with integration policies, the Brazilian market is still fragmented, although less so than China (Poncet, 2005). Actually, the internal border effect relative to intrastate trade stood at a ratio of 23 in 1991 and even fell to 13 in 1999. Note that, in 1999, a Brazilian state traded 460 times more with itself on average than with a foreign country.

In this paper, we use a similar approach to address a different issue. We take the gravity model methodology inspired by the "border effect" literature, not to quantify it using intra-state trade as a reference, but to shed light on the impacts of MERCOSUR on the direction of Brazilian state trade, comparing intra-Brazilian, intra-MERCOSUR and international trade.

We suggest that Brazil's openness to international trade in the 1990s, especially within MERCOSUR, triggered a shock that affected the trade-off between the different possible trade directions for Brazilian states. We could expect this openness to be detrimental to domestic trade, because some states might prefer to trade with relatively more accessible foreign countries instead of other states, especially in the MERCOSUR area. After the "shock", it might have been cheaper for Paulistan firms to export to opening Argentina than to Amazonian states. If this hypothesis were to hold, it would mean that Brazil's integration into regional (MERCOSUR) and world markets could undermine the traditional Brazilian objective to promote a more integrated Brazilian market. However, this assumption might be contradicted by the fact that greater international trade could induce more labor division and specialization within Brazil and then drive up interstate trade in an overall trend towards vertical specialization.

\section{Methodology and Data}

Recent empirical studies on the impact of regional trade agreements (RTAs) on countries' trade and post-McCallum "border effects" studies to measure intra-country trade volumes usually use gravity models, which estimate the expected bilateral trade using a number of control variables including size and different distance measurements (geographical, cultural, institutional, etc.). The challenge here is to link both separately measured issues. For this purpose, we need to consider Brazil not as a single integrated country, but as a huge customs union covering 27 different "countries" (the Brazilian States).

The gravity model used in this paper takes up the theoretical rationale put forward by Anderson \& van Wincoop (2003), which states that trade between two units depends on their bilateral trade costs and their trade costs with the rest of world. They call the latter Multilateral Resistance (MR) as it measures the country's trade costs with all its trade partners, which have to be included to prevent an omitted variable bias in the regression.

The gravity model $^{3}$ generated by the theory is:

$\ln \frac{X_{i j}}{Y_{i} Y_{j}}=k+(1-\sigma)\left[\ln t_{i}-\ln P_{i}-\ln P_{j}\right]$

where $t_{i j}$ is the bilateral trade cost between $i$ and $j$, while $h P_{i}$ and $h P_{j}$ are the logarithmic measurements of prices as an indicator of MR (e.g. high tariffs and non-tariff barriers imply higher domestic prices). This equation can be augmented with many structural and policy variables expected to have an impact on trade volumes as components of trade costs, e.g. contiguity, common language, common colonizer Regional Trade Agreements (RTAs).

The usual way of addressing MR is to introduce country fixed effects, which are dummy variables attached to each exporter or importer trade unit. Our empirical model uses this methodology and controls for multilateral resistance by introducing time invariant exporter and importer fixed effects for sample countries and Brazilian states. In addition to the basic variables in the traditional gravity model (exporter and importer GDPs, bilateral distance), we also control for contiguity (common border). In keeping with the trade creation-diversion literature, we augment the model introduced by A\&vW with the variables measuring MERCOSUR's trade impact: MERCOSUR's trade creation and diversion impact on Brazil's trade with the rest of the world and the preference erosion impact (trade shift from Brazilian domestic market to MERCOSUR countries). The creation of MERCOSUR constituted a shock

\footnotetext{
${ }^{3}$ See Deardorff (1998), Anderson and van Wincoop (2003), Feenstra (2004).
} 
for Brazil's domestic and foreign trade costs and changed the country's domestic and international trade structure. In fact, although MERCOSUR directly reduced trade costs between local units and member countries (e.g. Minas Gerais-Argentina), it also changed the relative level of Brazil's trade costs with third countries (e.g. Minas GeraisGermany) as well as relative costs among Brazilian States (e.g. Minas Gerais-Para), although these have remained unchanged in absolute terms.

Gravity models, long estimated using OLS, were challenged by Santos Silva \& Tenreyro (2006). In addition, many economists prefer the PPML (Poisson Pseudo Maximum of Likelihood) estimator over conventional log-normal methods in gravity equation estimations mainly due to the limits of log-normal specification in gravity models. First, the estimation methods calling for a logarithmic transformation give rise to inefficient estimated parameters and increase inconsistency since the error terms are heteroscedastic and their expected values depend on the model regressors (Jensen's Inequality). Second, the PPML estimator is a useful tool for dealing with zero trade values, which conceal a large amount of information explaining why some countries trade very little. Log-linearization, which returns zero trade values to missing data points, can cause a bias in the estimation, especially when the zero trade outcomes are not randomly distributed.

However, the PPML estimator's assumption of equidispersion $V\left[T_{i j} \mid x\right] \propto E\left[T_{i j} \mid x\right]$ considers the conditional variance of the dependent variable $\left(T_{i j}\right)$ to be equal to its conditional mean. Since this assumption is unlikely to hold, Santos \& Tenreyro (2006) recommend estimating statistical inferences based on an Eicker-White robust covariance matrix estimator.

Burger et al. (2009) posit that other Poisson family estimators (Negative Binomial and Zero Inflated Poisson) can be used depending on the reason why the conditional variance is higher than the conditional mean, due to overdispersion or excess zero trade values or both. From an economic point of view, negative binomial specification accounts for unobserved heterogeneity, which is generated by an omitted variable bias. The distribution equation of this specification is adjusted for the overdispersion. Yet its variance is a function of the conditional mean $(\mu)$ and the dispersion parameter $(\alpha)$. Another possible cause for the violation of the equidispersion assumption can be found in excess zeros in the trade volumes: the Zero-Inflated Poisson (ZIP) model (Lambert, 1992; Greene, 1994; Long, 1997) accounts for two latent groups. One is strictly zero for the entire sample period and the other presents positive trade potential, irrespective of whether they trade or not. The first part of the model is a logit regression estimating the probability of belonging to "never-trading group", while the second part is a Poisson regression.

Negative binomial specification introducing the overdispersion parameter in the distribution is an understandable statistical choice. However, unlike the zero-inflated Poisson specification, it does not provide an economic rationale for excess zeros. Furthermore, the negative binomial model is based upon a gamma mixture of Poisson distributions whose conditional variance is a quadratic function of its conditional mean. As Santos Silva \& Tenreyro (2006) put it, within the power-proportional variance functions, the estimators assuming conditional variance as being equal to higher powers of the conditional mean give more weight to observations from smaller countries whose data quality is questionable.

From this perspective, we consider that the zero-inflated model is a stronger methodological tool than the negative binomial model for solving the overdispersion problem in a gravity model of trade, since it has a theoretical rationale in addition to its statistical value ${ }^{4}$. Thus, in this paper, we use two estimators: a Poisson pseudo-maximum likelihood model (PPML) in line with Santos Silva \& Tenreyro (2006) and a zero-inflated Poisson pseudo-maximum likelihood model (ZIPPML) from the modified Poisson estimator family to deal with the overdispersion problem encountered in Poisson estimations of trade models.

Our basic gravity model explains bilateral exports based on the usual variables: GDP of the exporter $i$ and importer $j$, their bilateral distance and contiguity. However, since we work with cross-section time series data, the traditional model needs to be adjusted for distortions originating from price changes and shocks in world trade. Thus we introduce a time dummy for each year, which controls for fluctuations in dollar prices. Baldwin \& Taglioni (2006) also advocate time dummies in gravity equations instead of deflating the nominal trade values by the US aggregate

${ }^{4}$ Negative binomial models have been tested, but are not presented in this paper. 
price index, which they call a "bronze medal mistake" since the common global trends in inflation rates raise spurious correlations. We include country-fixed effects as previously justified. Then, our basic model is written as follows;

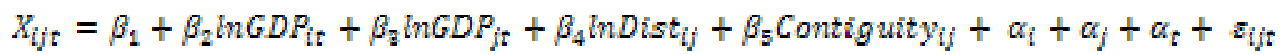

(Eq. 1)

where $X_{i j}$ is the export flow between the country (or Brazilian State) pair $i$ and $j$ in year $t$ and $D_{i s t_{i j}}$ is the bilateral distance. $G D P_{\mathrm{it}}$ and $G D P_{j \mathrm{t}}$ are the nominal gross domestic products of exporter country/state $i$ and importer country/state $j$ in year $t$. Contiguity $y_{i}$ takes value 1 if the trade pair $i j$ (state or country) shares a common border, which makes them neighbors. $\alpha_{i}$ and $\alpha_{j}$ are the country-fixed effects respectively for the exporter and the importer, $\alpha_{t}$ is the time-fixed effect. We inflate the model with the inDist $_{i j}$ and contiguity $y_{j}$ variables in ZIP estimations ${ }^{5}$.

The purpose of this paper is to consider the effect of MERCOSUR on trade among member countries, on interstate Brazilian trade and on Brazilian states' trade with third countries. The methodological choice is to introduce dummy variables for these three sets of bilateral relations, with a distinction made between the pre-MERCOSUR (1991) and post-MERCOSUR (1997 to 1999) period. Even constrained by the time lag between 1991 and 1997, we can consider that our data is relevant to capture the impact of MERCOSUR on Brazilian trade. While measuring MERCOSUR's bilateral trade impact, we also control for six other main RTAs in the world (ANDEAN, ASEAN, APTA, CACM, EC, and NAFTA).

In Equation 2, the star exponent indicates that the variables refer to the MERCOSUR period (1997 to 1999), while the pre-MERCOSUR period concerns 1991 only $(t=1991) . I S T_{i j t}{ }^{91}$ and $I S T_{j t}^{*}$ refer to interstate trade during the considered period taking value 1 when $i$ and $j$ are both Brazilian states (e.g. Minas Gerais-Para). MERCOSUR ${ }_{i j t}{ }^{{ }^{11}}$ and MERCOSUR $\mathbb{i j t}_{\text {ijt }}$ indicate trade between members of the MERCOSUR agreement, including trade between Brazilian states and member countries (e.g. Minas Gerais-Argentina and Uruguay-Argentina). By introducing the variable $M E R C O S U R_{i j t}{ }^{91}$, we expect to estimate the preliminary impact of MERCOSUR and see if there has been a relative increase in trade for the countries concerned after the establishment of MERCOSUR. $B R Z_{i j t^{91}}$ and $B R Z_{i j t}^{*}$ are dummy variables, which are equal to 1 for export flows from Brazilian states to non-MERCOSUR countries. A comparison of these two variables' coefficients will show the extent of Brazil's integration into the international market compared to international trade in the rest of the world. All these dummies in Equation 2 need to be interpreted relative to the reference group, which is equal to the bilateral trade structure of non-MERCOSUR countries, (e.g. China-Germany). The change in trade structure triggered by MERCOSUR can only be pointed up by comparing pre- and post-MERCOSUR years.

$X_{i t}=$

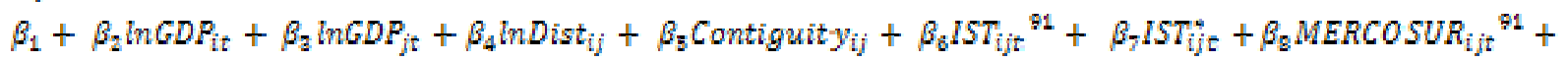
$\beta_{g} M E R C O S U R_{i j t}^{4}+\beta_{10} B R Z_{i j t}{ }^{91}+\beta_{11} B R Z_{i j t}^{4}+\beta_{12} R T A_{i j t}+\alpha_{i}+\alpha_{j}+\alpha_{t}+\varepsilon_{i j t}$

$(E q .2)$

Since the impact of an RTA can vary over time, our analysis goes further by conducting a yearly decomposition of the variables of interest in Equation 2. As mentioned by Frankel (1997), the period before and after the agreement enters into force has an impact on the annual extent of trade creation and trade diversion considered ${ }^{6}$. The time-fixed effect introduced in the equation cannot specifically take into account this timely evolution in the impact of MERCOSUR on trade. We therefore isolate the three years (1997, 1998 and 1999) by decomposing our variable of interest (interstate, intra-MERCOSUR and trade with third countries).

5Frankel (1997) states that zero trade outcomes c ome mostly from a lack of trade between small and distant countries. Rauch (1999) adds a lack of historical and cultural links as a possible reason $f_{\text {or }}$ zero trade between country pairs.

${ }^{6}$ Magee (2008) posits that the agreement has no cumulative impact after its 11th year of being in effect. 
However, caution is called for when interpreting evolution of the RTA's impact, because country-specific shocks can have a huge impact on members' trade volumes and bias the annual estimates. Thus we introduce time-varying country-fixed effects into our robustness test, which controls for specific economic shocks such as policy changes and recession as these shocks can have an impact on trade specifically within MERCOSUR (e.g. the 1999 Brazilian crisis with the depreciation of the Real against other currencies, including the Argentinean peso).

We use balanced panel data covering the export values of the 27 Brazilian states and 118 countries (see annex) for 1991, 1997, 1998 and 1999. So the data consist of subgroups of trade pairs, with a different data source used for each. We draw on the export values of the 27 states trading with one another $\left(27^{*} 26\right)$, their trade with other countries $\left(27^{*} 118^{*} 2\right)$ and the trade of the 118 countries with one another $\left(118^{*} 117\right)$, all for four years and balanced for the pairs with missing values while keeping zero values.

The Brazilian states' international trade flows are taken from $\mathrm{ALICEWEB}^{7}$, and containing the export and import values for Brazilian states to and from each country. The export values of the 118 countries trading with one another are taken from the Directory of Trade Statistics (DOTs) published by the International Monetary Fund. Both sources concur and can be combined since they present similar total export volumes for all Brazilian trade with sample countries.

We also use Brazilian interstate export flows for our empirical study. Domestic tax regulation introduced by the federal system gives us bilateral export data on the Brazilian states for 1991, 1997, 1998 and 1999. The Brazilian authorities use the information from the ICMS tax accounts to measure interstate trade flows. The ICMS tax (Imposto sobre Circulação de Mercadorias e Serviços) is a type of value added tax (VAT) collected by the exporting State $^{8}$. From this information delivered by the Brazilian Ministry of Finance, it has been constructed a database for 1997 (Ministério de Fazenda, 2000), 1998 and 1999 (Vasconcelos, 2001a, 2001b). The 1991 data come from SEFAZ-PE (1993) ${ }^{9}$ and are measured and extrapolated by the Pernambuco Finance Ministry from the 1987 interstate database. Unfortunately, lack of data for a longer period and gaps between 1991 and 1997 place limitations on the study. However, we believe we can cover a large part of the shock triggered by the launch of MERCOSUR, since it came into effect in late November 1991 and was scaled up in 1994 by the Treaty of Ouro Preto.

GDP values for the countries are given in current dollars and drawn from the World Bank's World Development Indicators database. GDP values for the Brazilian states are provided by the IBGE (Instituto Brasileiro de Geografia e Estatística) in local currency units, in Cruzeiro for 1991 and in Real for the following years. Given that the exchange rate from Cruzeiro to current dollars is not provided by the $W D I$, we calculate the ratio of state GDP to total Brazilian GDP based on the IBGE database presented in local currency units and multiply it by the total GDP of Brazil in current dollars provided by the WDI. For 1997, 1998 and 1999, the ratios turn up similar results to those calculated by the WDI exchange rates, which confirms the 1991 values of state GDP.

The distance and contiguity variables are taken from CEPII's Distances database. For the most part, the capital cities are the main unit of the distance measurements. However, the data occasionally also use the economic capital as the geographic center of the country. The World Gazetteer website furnishes the geographical coordinates of the state's capital from which we have calculated the states' bilateral distances from one another and the other countries. The information on state contiguity is taken directly from the map of Brazil.

\section{Results and Robustness Check}

In Table 1, the basic gravity model (Model 1) presents coefficients similar to those usually found in the literature. We find very close $\beta$ values with both estimators, PPML (Poisson Pseudo Maximum of Likelihood) and ZIPPML (Zero Inflated Poisson). Income elasticity is generally less than 1 for both estimators, which means that large countries trade relatively less than small countries. We hence relax the A\&vW (2003) hypothesis of unitary

\footnotetext{
${ }^{7}$ Secretaria de Comércio Exterior (Secex) do Ministério do Desenvolvimento, Indústria e Comércio Exterior (MDIC).

${ }^{8}$ We also use the terms "export" and "import" for trade between two Brazilian states (e.g. São Paulo-Minas Gerais).

${ }^{9}$ See Daumal and Zignago (2010).
} 
elasticity. The logit regression finds that distance between countries increases the probability of zero trade, while sharing a common border decreases it. Since the coefficients are significantly different from zero and concur in sign and value with the theory, our choice of using ZIPPML over PPML is strengthened from an econometric point of view even though the results are quite similar. The significantly positive Vuong (1989) statistic also favors ZIPPML over PPML. The same holds true for the Akaike Information Criterion and the Bayesian Information Criterion, which are smaller in the ZIPPML model.

Starting with Model 2, we measure the impact of MERCOSUR based on Equation 2 augmented with dummy variables controlling for different groups of trade pairs over time and among subgroups. Their coefficients are to be interpreted compared to the reference group, that is bilateral trade between non-MERCOSUR countries. All coefficients are significant. The interstate trade coefficients are higher than the intra-MERCOSUR trade coefficients for the entire period, which provides evidence of a home bias ${ }^{10}$. The coefficients for Brazilian foreign trade with third countries are significantly negative for the entire period. The first conclusion is that Brazilian states trade more with one another than with other countries, even within MERCOSUR, and that their integration into world trade is relatively weak on average. The second conclusion concerns the comparison between the pre- and post-MERCOSUR period (MERCOSUR and MERCOSUR ${ }^{*}$ ). The coefficients for interstate trade (IST and IST ${ }^{*}$ ) and international trade $\left(B R Z\right.$ and $\left.B R Z^{*}\right)$ are not significantly affected, although they are slightly lower for the post-MERCOSUR period, while intra-MERCOSUR trade is significantly higher after the establishment of MERCOSUR. These first results are consistent with the hypothesis that MERCOSUR had a trade creation effect within the area, without triggering either a decrease in trade among Brazilian states or a decrease in Brazilian trade with third countries.

In Model 3, we decompose the impact of MERCOSUR for each year using the pooled cross-section time series data. It has long been argued that the impact of an RTA is not uniform over time. However, the decomposition is particularly important in the Brazilian case. In this way, we can observe if the deterioration in the economic situation of Brazil and Argentina at the end of 1990s (devaluation of the Brazilian Real in 1999) had an impact on MERCOSUR's trade performance as well as on Brazilian interstate trade. Descriptive statistics show that the value of Brazilian exports to MERCOSUR fell 24\% between 1998 and $1999^{11}$. This drop is expected to have benefited Brazilian interstate trade, but it has to be balanced out by the consequences of the economic recession. In order to take a closer look at this development, we replace $\beta_{7} I S T_{i j t}^{*}$ with $\sum_{g=97}^{92} \beta_{i s t} I S T_{i j t}^{*} ; \beta_{9} M E R C O S U R_{i j t}^{*}$ with

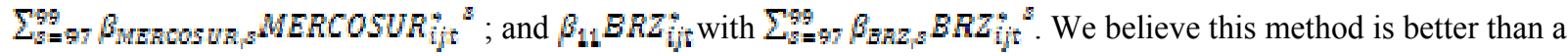
strict cross-section analysis conducted separately for each year, where the gravity benchmark is different for each year and hence vulnerable to yearly fluctuations and shocks in world trade. In the pooled panel data, given that we use a single control group for all years, the coefficients are comparable with one another and over time ${ }^{12}$.

Annual decomposition of the IST variable to identify differences over the four available years (Model 3) finds a small change in the key variables' general trends. We observe a small downturn in the impact of MERCOSUR's creation on trade followed by an increase in interstate trade and Brazilian trade with non-member countries in 1999. However, the change is not statistically significant and is negligible in value. Thus, Model 3 confirms our previous conclusion: MERCOSUR created trade without generating any significant loss in trade among states or in Brazilian trade with third countries.

\section{Table 1: Annual decomposition of MERCOSUR impact}

\footnotetext{
${ }^{10}$ However, the value of the IST coefficient cannot be considered to measure the Brazilian border effect in traditional literature terms. Border effect is commonly measured in the literature by the scale of domestic trade compared to the country's trade with the rest of world. In our analysis, however, the reference is the trade of nonMERCOSUR countries.

${ }^{11}$ From WTO, Table III-24.

${ }^{12}$ For the reader's information, we did after all attempt to present the estimation results taken from the cross-section analysis. Unfortunately, PPML and ZIPPML do not converge for all the years (STATA), especially for 1991, which is vital to an evaluation of the impact of MERCOSUR since it is the only year in the sample before its creation.
} 


\begin{tabular}{|c|c|c|c|c|c|c|c|c|c|}
\hline \multirow{3}{*}{$\begin{array}{c}\text { Table } 1 \\
\text { Dependent } \\
\text { Variable } \boldsymbol{X}_{\mathrm{wt}}^{\text {a }}\end{array}$} & \multirow{3}{*}{$\begin{array}{c}\text { Model } 1 \\
\text { PPML } \\
\end{array}$} & \multicolumn{2}{|c|}{ Model 1} & \multirow{3}{*}{$\begin{array}{c}\text { Model } 2 \\
\\
\text { PPML } \\
\end{array}$} & \multicolumn{2}{|c|}{ Model 2} & \multirow{3}{*}{$\begin{array}{c}\text { Model } 3 \\
\\
\text { PPML } \\
\end{array}$} & \multicolumn{2}{|c|}{ Model 3} \\
\hline & & \multicolumn{2}{|c|}{ Zero-inflated PPML } & & \multicolumn{2}{|c|}{ Zero-inflated PPML } & & \multicolumn{2}{|c|}{ Zero-inflated PPML } \\
\hline & & Logit & Poisson & & Logit & Poisson & & Logit & Poisson \\
\hline \multirow[t]{2}{*}{ ln_gdpnominali } & $0.454 *$ & & $0.451 *$ & $0.450^{*}$ & & $0.449^{*}$ & $0.485^{*}$ & & $0.482 *$ \\
\hline & $(0.127)$ & & $(0.127)$ & $(0.115)$ & & $(0.115)$ & $(0.134)$ & & $(0.134)$ \\
\hline \multirow[t]{2}{*}{ ln_gdpnominalj } & $0.697^{*}$ & & $0.683^{*}$ & $0.710^{*}$ & & $0.700^{*}$ & $0.748^{*}$ & & $0.736^{*}$ \\
\hline & $(0.123)$ & & $(0.123)$ & $(0.112)$ & & $(0.112)$ & $(0.131)$ & & $(0.131)$ \\
\hline \multirow[t]{2}{*}{ ln_distance } & $-0.822 *$ & $0.560^{*}$ & $-0.818^{*}$ & $-0.621^{*}$ & $0.709^{*}$ & $-0.618^{*}$ & $-0.621^{*}$ & $0.709^{*}$ & $-0.618^{*}$ \\
\hline & $(0.016)$ & $(0.021)$ & $(0.016)$ & $(0.017)$ & $(0.027)$ & $(0.017)$ & $(0.017)$ & $(0.027)$ & $(0.017)$ \\
\hline \multirow[t]{2}{*}{ contiguity } & $0.684^{*}$ & $-1.116^{*}$ & $0.686^{*}$ & $0.690 *$ & $-0.784^{*}$ & $0.691^{*}$ & $0.690^{*}$ & $-0.781 *$ & $0.691^{*}$ \\
\hline & $(0.060)$ & $(0.216)$ & $(0.059)$ & $(0.058)$ & $(0.237)$ & $(0.058)$ & $(0.058)$ & $(0.236)$ & $(0.058)$ \\
\hline \multirow[t]{2}{*}{$R T A$} & & & & $0.407 *$ & & $0.415^{*}$ & $0.408^{*}$ & & $0.416^{*}$ \\
\hline & & & & $(0.047)$ & & $(0.047)$ & $(0.047)$ & & $(0.047)$ \\
\hline \multirow[t]{2}{*}{$I S T^{* 91}$} & & & & $2.592 *$ & & $2.563^{*}$ & $2.614^{*}$ & & $2.585^{*}$ \\
\hline & & & & $(0.303)$ & & $(0.300)$ & $(0.304)$ & & $(0.301)$ \\
\hline \multirow[t]{2}{*}{$I S T^{*}$} & & & & $2.460 *$ & & $2.435^{*}$ & & & \\
\hline & & & & $(0.295)$ & & $(0.291)$ & & & \\
\hline \multirow[t]{2}{*}{$I S T^{* 97}$} & & & & & & & $2.445^{*}$ & & $2.422 *$ \\
\hline & & & & & & & $(0.299)$ & & $(0.296)$ \\
\hline$I S T * 98$ & & & & & & & $2.408^{*}$ & & $2.384 *$ \\
\hline & & & & & & & $(0.298)$ & & $(0.294)$ \\
\hline$I S T^{* 99}$ & & & & & & & $2.564^{*}$ & & $2.535^{*}$ \\
\hline & & & & & & & $(0.303)$ & & $(0.300)$ \\
\hline MERCOSUR *91 & & & & $0.508^{*}$ & & $0.481^{* *}$ & $0.524^{*}$ & & $0.496 * *$ \\
\hline & & & & $(0.193)$ & & $(0.192)$ & $(0.195)$ & & $(0.194)$ \\
\hline MERCOSUR* ${ }^{*}$ & & & & $1.149^{*}$ & & $1.122 *$ & & & \\
\hline & & & & $(0.168)$ & & $(0.167)$ & & & \\
\hline MERCOSUR*97 & & & & & & & $1.149^{*}$ & & $1.122 *$ \\
\hline & & & & & & & $(0.196)$ & & $(0.195)$ \\
\hline MERCOSUR*98 & & & & & & & $1.170^{*}$ & & $1.143^{*}$ \\
\hline & & & & & & & $(0.189)$ & & $(0.188)$ \\
\hline MERCOSUR*99 & & & & & & & $1.124^{*}$ & & $1.094 *$ \\
\hline & & & & & & & $(0.191)$ & & $(0.190)$ \\
\hline$B R Z * 91$ & & & & $-0.904 *$ & & $-0.887^{*}$ & $-0.892 *$ & & $-0.876^{*}$ \\
\hline & & & & $(0.153)$ & & $(0.151)$ & $(0.154)$ & & $(0.152)$ \\
\hline$B R Z^{*}$ & & & & $-0.834^{*}$ & & $-0.828^{*}$ & & & \\
\hline & & & & $(0.145)$ & & $(0.143)$ & & & \\
\hline$B R Z * 97$ & & & & & & & $-0.857 *$ & & $-0.850^{*}$ \\
\hline & & & & & & & $(0.158)$ & & $(0.157)$ \\
\hline$B R Z * 98$ & & & & & & & $-0.883^{*}$ & & $-0.876^{*}$ \\
\hline & & & & & & & $(0.159)$ & & $(0.157)$ \\
\hline$B R Z * 99$ & & & & & & & $-0.750^{*}$ & & $-0.744^{*}$ \\
\hline & & & & & & & $(0.158)$ & & $(0.157)$ \\
\hline Constant & $-21.018^{*}$ & $-6.490^{*}$ & $-19.634 *$ & $-23.239^{*}$ & $-8.220 *$ & $-22.775^{*}$ & $-24.725^{*}$ & $-8.218^{*}$ & $-24.197 *$ \\
\hline & $(3.791)$ & $(0.196)$ & $(3.808)$ & $(3.528)$ & $(0.246)$ & $(3.523)$ & $(4.496)$ & $(0.246)$ & $(4.490)$ \\
\hline Observations & 78580 & 78580 & 78580 & 78580 & 78580 & 78580 & 78580 & 78580 & 78580 \\
\hline $\begin{array}{l}\text { Importer fixed } \\
\text { effects }\end{array}$ & Yes & & Yes & Yes & & Yes & Yes & & Yes \\
\hline $\begin{array}{l}\text { Exporter fixed } \\
\text { effects }\end{array}$ & Yes & & Yes & Yes & & Yes & Yes & & Yes \\
\hline Time fixed effects & Yes & & Yes & Yes & & Yes & Yes & & Yes \\
\hline $\begin{array}{l}-2 \text { log pseudo- } \\
\text { likelihood }\end{array}$ & 7542282 & & 7383215 & 6034688 & & 5908698 & 6032248 & & 5906426 \\
\hline Vuong $(z)$ & & & $28.40^{*}$ & & & $23.83^{*}$ & & & $23.87^{*}$ \\
\hline AIC & 7542874 & & 7383813 & 6035275 & & 5909311 & 6032867 & & 5907050 \\
\hline $\mathrm{BIC}$ & 7545619 & & 6500841 & 6038084 & & 5026404 & 6035732 & & 5024199 \\
\hline
\end{tabular}

${ }^{a}$ Dependent variable is scaled by $10^{6}$. Robust standard errors in parentheses: All inferences are based on a Huber-White sandwich estimate of variance. $* * *$ Significant at $10 \% ; * *$ significant at $5 \% ; *$ significant at $1 \%$.

In the next step, we present the results for the different versions of Model 3, considered as a benchmark and modified in order to check its robustness. 
In the first column (version 1) of Table 2, we introduce into the model two new measurements of cultural and/or historical distance taken from CEPII's Distances database. The colony $i j$ dummy indicates whether two countries have ever had a colonial relationship and comlang_ethno $\sigma_{j}$ is equal to one if a language is spoken by at least $9 \%$ of the population in both countries. Both variables are significantly different from zero and decrease the probability of being in the zero trading country pair group. These two dummies partially capturing trade between states by means of trade cost measurements decrease the value of the IST coefficient. However, it is always greater than intraMERCOSUR trade. The values and change over time of MERCOSUR's trade creation and trade diversion impact are similar to previous results and evidence of the robustness of the model.

In the $3 r d$ and 4 th versions, the results are found in order, after dropping Brasília (Distrito Federal) and Amazonas, which are two potential outliers. Brasília is a state planned and built as of 1956 with the objective of transferring the country's capital from Rio de Janeiro. Its economic activity is hence driven mostly by demand from the local population, who are basically occupied in bureaucratic jobs, and satisfied mainly by imports from other states while exports are abnormally low compared to the other states. The state of Amazonas can also be considered to be an exceptional case like Brasília, although for different reasons. It potentially presents different trade patterns to other Brazilian states since it benefits from preferential tax regulations (e.g. lower interstate ICMS rates) for its business within the country and special trade incentives (exemptions from export and import taxes) within the Manaus Free Trade Zone, which accounts for the largest proportion of state production. This area is the number two high-tech district (after São Paolo) despite its location deep in the Amazonian forest without road access. This makes the state of Amazonas a highly specific case.

However, after controlling for specific trade patterns in Brasília (D.F.) and Amazonas by dropping them, the results remain unchanged. Thus, our fixed effects are correctly capturing the particular characteristics of trade units and the model is robust to the heterogeneity.

Another issue that makes an empirical analysis of MERCOSUR's impact vulnerable is the volatility of Brazil and Argentina's economies, the two foremost members of MERCOSUR in terms of their economic size, in the $1990 \mathrm{~s}{ }^{13}$. The economic volatility of the MERCOSUR region over the period of analysis prompted us to introduce timevarying country-fixed effects into the model represented in the second column of Table 2 (version 2).

Time-varying country-fixed effects - in addition to accounting for the domestic level of prices, which is an indicator of the Multilateral Resistance term in the theory - also account for time-varying characteristics specific to the trade unit (country/state) that have an impact on trade values such as recessions, economic or structural policy changes, and exchange rates. Replacing time-constant country-fixed effects with time-varying country-fixed effects adds a control for events specifically affecting one country. However, the huge number of dummies and the cumbersome iteration procedure make it extremely hard to obtain results due to convergence problems in the PPML and ZIPPML estimation procedure. Hopefully, the results we have provide some useful insights ${ }^{14}$.

In Model 3-Version 2, after controlling for Brazil's economic deterioration in late 1990s and other time-varying characteristics in the sample, we observe a drop in interstate trade with MERCOSUR and then an upturn through to 1999. However, a clear conclusion cannot easily be drawn since the Fisher statistics show that we cannot significantly reject the hypothesis of the equality of coefficients. As regards the trade creation variable (MERCOSUR: ijt $^{s}$ ), the introduction of time-varying fixed effects shows that trade between MERCOSUR members increases steadily and continuously even in 1999, which indicates that the collapse of trade within MERCOSUR was caused by recession in member countries rather than by a slowdown in regional integration.

\section{Table 2: Robustness Analyses}

\footnotetext{
${ }^{13}$ The first period of the 1990s was marked by high inflation rates for both countries (inflationary pressure continued in Brazil until Plano Real in 1994 and in Argentina until 1993). Exchange rates were also highly volatile. The Brazilian Real was sharply devaluated in 1999. A recession started in Argentina in 1999 and continued with the crisis of 2001-2002 and the devaluation of peso.

${ }^{14}$ Unfortunately, due to computational limits, we are unable to measure Vuong statistics for this version of the model.
} 


\begin{tabular}{|c|c|c|c|c|c|c|c|c|}
\hline \multirow[t]{3}{*}{$\begin{array}{l}\text { Table } 2 \\
\text { Dependent Variable } \\
X_{\text {d, a }}\end{array}$} & \multirow{2}{*}{\multicolumn{2}{|c|}{ Model 3_Augmented (1) }} & \multirow{2}{*}{\multicolumn{2}{|c|}{$\begin{array}{c}\text { Model 3_time varying fixed } \\
\text { effects } \\
(2)\end{array}$}} & \multicolumn{2}{|c|}{$\begin{array}{c}\text { Model 3_Without state of } \\
\text { Brasília(3) }\end{array}$} & \multicolumn{2}{|c|}{$\begin{array}{c}\text { Model 3_Without state of } \\
\text { Amazonas(4) }\end{array}$} \\
\hline & & & & & Zero-in & d PPML & Zero-ir & PPML \\
\hline & Logit & Poisson & Logit & Poisson & Logit & Poisson & Logit & Poisson \\
\hline \multirow[t]{2}{*}{ ln_gdpnominali } & & $0.478^{*}$ & & & & $0.481^{*}$ & & $0.482 *$ \\
\hline & & $(0.127)$ & & & & $(0.134)$ & & $(0.134)$ \\
\hline \multirow[t]{2}{*}{ ln_gdpnominalj } & & $0.736^{*}$ & & & & $0.737 *$ & & $0.735^{*}$ \\
\hline & & $(0.126)$ & & & & $(0.131)$ & & $(0.131)$ \\
\hline \multirow[t]{2}{*}{ ln_distance } & $0.608^{*}$ & $-0.592 *$ & $0.726^{*}$ & $-0.618^{*}$ & $0.699 *$ & $-0.617^{*}$ & $0.703 *$ & $-0.619^{*}$ \\
\hline & $(0.027)$ & $(0.016)$ & $(0.028)$ & $(0.017)$ & $(0.027)$ & $(0.017)$ & $(0.027)$ & $(0.017)$ \\
\hline \multirow[t]{2}{*}{ contiguity } & $-.0681^{*}$ & $0.496^{*}$ & $-0.948^{*}$ & $0.689^{*}$ & $-0.770 *$ & $0.693 *$ & $-0.731^{*}$ & $0.693^{*}$ \\
\hline & $(0.255)$ & $(0.054)$ & $(0.288)$ & $(0.058)$ & $(0.236)$ & $(0.058)$ & $(0.235)$ & $(0.058)$ \\
\hline \multirow[t]{2}{*}{ colony } & $-1.852^{*}$ & -0.018 & & & & & & \\
\hline & $(0.206)$ & $(0.050)$ & & & & & & \\
\hline \multirow[t]{2}{*}{ comlang_ethno } & $-.206^{*}$ & $0.540^{*}$ & & & & & & \\
\hline & $(0.058)$ & $(0.039)$ & & & & & & \\
\hline \multirow{2}{*}{$R T A$} & & $0.486^{*}$ & & $0.423^{*}$ & & $0.416^{*}$ & & $0.413^{*}$ \\
\hline & & $(0.043)$ & & $(0.050)$ & & $(0.047)$ & & $(0.047)$ \\
\hline \multirow[t]{2}{*}{$I S T * 91$} & & $1.774^{*}$ & & $2.841^{*}$ & & $2.562 *$ & & $2.545^{*}$ \\
\hline & & $(0.309)$ & & $(0.400)$ & & $(0.301)$ & & $(0.302)$ \\
\hline \multirow[t]{2}{*}{$I S T^{* 97}$} & & $1.623^{*}$ & & $2.057^{*}$ & & $2.400^{*}$ & & $2.374^{*}$ \\
\hline & & $(0.304)$ & & $(0.494)$ & & $(0.296)$ & & $(0.297)$ \\
\hline \multirow[t]{2}{*}{$I S T * 98$} & & $1.586^{*}$ & & $2.402 *$ & & $2.365^{*}$ & & $2.342 *$ \\
\hline & & $(0.303)$ & & $(0.479)$ & & $(0.294)$ & & $(0.296)$ \\
\hline \multirow[t]{2}{*}{$I S T * 99$} & & $1.735^{*}$ & & $2.868^{*}$ & & $2.517^{*}$ & & $2.490^{*}$ \\
\hline & & $(0.307)$ & & $(0.528)$ & & $(0.300)$ & & $(0.301)$ \\
\hline \multirow[t]{2}{*}{ MERCOSUR *91 } & & $0.535^{*}$ & & $0.820^{*}$ & & $0.493 * *$ & & $0.490 * *$ \\
\hline & & $(0.194)$ & & $(0.227)$ & & $(0.194)$ & & $(0.197)$ \\
\hline \multirow[t]{2}{*}{ MERCOSUR *97 } & & $1.174 *$ & & $0.900^{*}$ & & $1.122^{*}$ & & $1.116^{*}$ \\
\hline & & $(0.195)$ & & $(0.280)$ & & $(0.196)$ & & $(0.197)$ \\
\hline MERCOSUR*98 & & $1.194 *$ & & $1.060^{*}$ & & $1.143 *$ & & $1.135^{*}$ \\
\hline & & $(0.190)$ & & $(0.284)$ & & $(0.189)$ & & $(0.190)$ \\
\hline MERCOSUR*99 & & $1.144^{*}$ & & $1.292^{*}$ & & $1.094 *$ & & $1.081^{*}$ \\
\hline & & $(0.191)$ & & $(0.300)$ & & $(0.191)$ & & $(0.192)$ \\
\hline$B R Z * 91$ & & $-1.036^{*}$ & & $-0.733^{*}$ & & $-0.876^{*}$ & & $-0.870 *$ \\
\hline & & $(0.152)$ & & $(0.201)$ & & $(0.152)$ & & $(0.153)$ \\
\hline$B R Z * 97$ & & $-0.991^{*}$ & & $-1.052 *$ & & $-0.850^{*}$ & & $-0.868^{*}$ \\
\hline & & $(0.157)$ & & $(0.250)$ & & $(0.157)$ & & $(0.160)$ \\
\hline$B R Z * 98$ & & $-1.015^{*}$ & & $-0.877^{*}$ & & $-0.875^{*}$ & & $-0.881^{*}$ \\
\hline & & $(0.157)$ & & $(0.242)$ & & $(0.157)$ & & $(0.160)$ \\
\hline$B R Z * 99$ & & $-0.885^{*}$ & & $-0.578 * *$ & & $-0.749^{*}$ & & $-0.754 *$ \\
\hline & & $(0.157)$ & & $(0.265)$ & & $(0.157)$ & & $(0.160)$ \\
\hline Constant & $-7.294 *$ & $-24.083^{*}$ & $-8.406^{*}$ & $5.163^{*}$ & $-8.137 *$ & $-24.192^{*}$ & $-8.171^{*}$ & $-24.116^{*}$ \\
\hline & $(0.250)$ & $(4.190)$ & $(0.256)$ & $(0.403)$ & $(0.246)$ & $(4.491)$ & $(0.247)$ & $(4.489)$ \\
\hline Observations & 78580 & 78580 & 78580 & 78580 & 77516 & 77516 & 77516 & 77516 \\
\hline Importer fixed effects & & Yes & & & & Yes & & Yes \\
\hline Exporter fixed effects & & Yes & & & & Yes & & Yes \\
\hline $\begin{array}{l}\text { Time varying exporter } \\
\text { fixed effects }\end{array}$ & & & & Yes & & & & \\
\hline $\begin{array}{l}\text { Time varying importer } \\
\text { fixed effects }\end{array}$ & & & & Yes & & & & \\
\hline Time fixed effects & & Yes & & Yes & & Yes & & Yes \\
\hline $\begin{array}{l}-2 \text { log pseudo- } \\
\text { likelihood }\end{array}$ & & 5577560 & & 5725222 & & 5892185 & & 58844816 \\
\hline Vuong $(z)$ & & $22.82 *$ & & - & & $23.80 *$ & & $23.77 *$ \\
\hline $\mathrm{AIC}$ & & 5578192 & & 5727586 & & 5892809 & & 5845440 \\
\hline $\mathrm{BIC}$ & & 4695378 & & 4852802 & & 5023004 & & 4975635 \\
\hline
\end{tabular}

However, compared with our reference model, the trade creation effect of MERCOSUR appears lower when we consider country-fixed effects to be time varying. Thus, the trade creation impact of MERCOSUR is questionable because the assumption of coefficient equality is not rejected by the Fisher statistics - unless the higher coefficient in 1991 is attributed to the preliminary impact of the agreement. Brazilian trade with non-member countries $\left(B R Z_{\mathrm{ijt}}^{*}\right)$ 
follows the same trend as interstate trade, with an initial drop in trade volumes followed by a steady increase. However, the Fisher statistics are always non-significant. Yet we do believe that Brazil's specialization patterns changed slightly by creating new trade opportunities over the period, although only an analysis conducted at sector level could give clearer results on this.

\section{Regional Decomposition of the Impact of MERCOSUR}

In Table 1, we have previously seen that MERCOSUR creates trade without significantly reducing trade with nonmember countries and among Brazilian states. This means that there is no evidence of a "preference erosion" effect in Brazil. Yet this result is not necessarily clear-cut for all regions and states of Brazil. Indeed, MERCOSUR's impact can vary depending on regional differences in production structure. In the Brazilian case, it is particularly important to decompose the aggregate impact in regional terms, since there are substantial regional disparities among states' economic development levels and huge differences in specialization patterns. Where the MERCOSUR's "preference erosion" effect might undermine uncompetitive activities in some regions and reduce interstate trade, this effect could be offset by a domestic specialization process. So in order to find the size and direction of the international trade impact by region, we decompose MERCOSUR's Trade Creation (MERCOSUR $i j)$ and Trade Diversion impact $\left(B R Z_{i j t}\right)$ in regional terms.

We use the Instituto Brasileiro de Geografia e Estatística (IBGE)'s regional nomenclature for our regional decomposition. The IBGE divides Brazil into five macro-regions. We use this macro-level division: namely South, South-East, North-East, Center-West and North (see the map in the annex). The IBGE endeavors to group together states with similar cultural, economic, historical and social characteristics in the same region, provided they are geographically clustered. Thus there is minimum uniformity within each regional division and the study at regional level provides enough information to capture the differences in trade impact.

We decompose MERCOSUR's trade creation and diversion impact for each region by introducing a bilateral dummy for the period before and after MERCOSUR. Thus we have $k=5$ dummies of the trade creation variable for the pre-

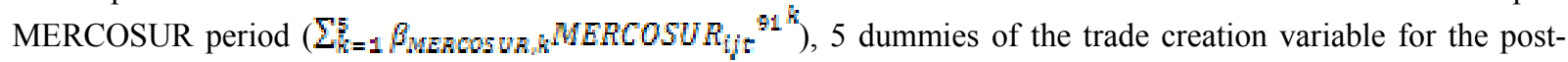

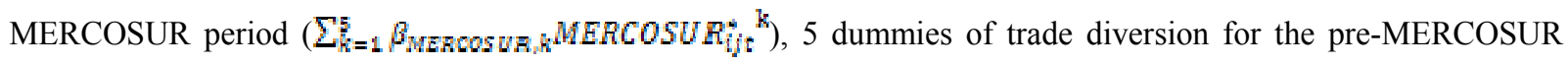
period $\left(\sum_{k=1}^{5} \beta_{B A Z k} B R Z_{1}^{k}\right)$, and 5 dummies of trade diversion for the post-MERCOSUR period

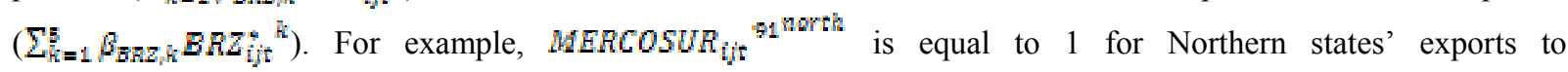
MERCOSUR members as well for their imports from member countries in 1991. We also introduce a dummy for the pair of MERCOSUR countries other than Brazilian states (mercosur memb). For ease of reading, the results in Table 3 are presented horizontally for post- and pre-MERCOSUR dummies. The results for the basic control variables (GDP, distance, contiguity, RTA, etc.) in Equation 2 are not given in this table since they concur with previous results. We also conduct a Fisher test to control for whether the difference in the value of the coefficients is statistically significant. Both methods of estimation produce very similar results.

The results show that MERCOSUR has significantly (Fisher test) created trade in all regions except the Center-West (with a low positive impact in the North). The South-Eastern states, already strongly integrated, have posted a huge increase. This is not surprising since this region, where São Paulo and Rio de Janeiro are located, is economically the most developed part of Brazil. The Southern and, more surprisingly, North-Eastern states have also benefited, albeit less so, from the creation of MERCOSUR. The North-East has probably benefited from a relative relocation of businesses prompted by incentives and lower labor costs. Yet while the North has slightly increased its trade with MERCOSUR countries, it remains relatively less integrated. Center-West economic activity has not benefited from the establishment of MERCOSUR.

TABLE 3: Regional Decomposition of the Impact of MERCOSUR 


\begin{tabular}{|c|c|c|c|c|c|c|}
\hline \multirow{2}{*}{$\frac{\text { Table } 3}{\text { Dependent Variable } \boldsymbol{X}_{\mu \mathbf{k}}{ }^{\mathrm{a}}}$} & \multicolumn{2}{|c|}{ PPML } & \multirow[b]{2}{*}{$\begin{array}{l}\text { Fisher Test } \\
\text { of equality }\end{array}$} & \multicolumn{2}{|c|}{ Zero-inflated PPML } & \multirow[b]{2}{*}{$\begin{array}{l}\text { Fisher Test } \\
\text { of equality }\end{array}$} \\
\hline & $\begin{array}{c}\text { Pre- } \\
\text { MERCOSUR } \\
\text { period }\end{array}$ & $\begin{array}{c}\text { Post- } \\
\text { MERCOSUR } \\
\text { period }\end{array}$ & & $\begin{array}{c}\text { Pre- } \\
\text { MERCOSUR } \\
\text { period }\end{array}$ & $\begin{array}{c}\text { Post- } \\
\text { MERCOSUR } \\
\text { period }\end{array}$ & \\
\hline & $\beta$ & $\beta$ & $x^{7}(1)$ & $\beta$ & $\beta$ & $x^{2}(1)$ \\
\hline \multirow[t]{2}{*}{$I S T$} & $2.908^{*}$ & $2.776^{*}$ & 2.21 & $3.029 *$ & $2.900 *$ & 2.11 \\
\hline & $(0.595)$ & $(0.561)$ & & $(0.581)$ & $(0.546)$ & \\
\hline \multirow[t]{2}{*}{ MERCOSUR_north } & -0.600 & 0.020 & $3.37 * * *$ & -0.523 & 0.068 & $2.84+$ \\
\hline & $(0.442)$ & $(0.324)$ & & $(0.452)$ & $(0.325)$ & \\
\hline \multirow[t]{2}{*}{ MERCOSUR_south } & 0.277 & $0.953^{*}$ & $5.91 * *$ & 0.318 & $0.999 *$ & $6.12 * *$ \\
\hline & $(0.405)$ & $(0.310)$ & & $(0.398)$ & $(0.302)$ & \\
\hline \multirow[t]{2}{*}{ MERCOSUR_northeast } & 0.382 & $1.061 *$ & $9.09 *$ & 0.420 & $1.105^{*}$ & $9.05 *$ \\
\hline & $(0.369)$ & $(0.309)$ & & $(0.364)$ & $(0.303)$ & \\
\hline \multirow[t]{2}{*}{ MERCOSUR_southeast } & $1.029^{*}$ & $1.707 *$ & $26.95 *$ & $1.069^{*}$ & $1.753 *$ & $27.60^{*}$ \\
\hline & $(0.330)$ & $(0.295)$ & & $(0.324)$ & $(0.289)$ & \\
\hline \multirow[t]{2}{*}{ MERCOSUR_centerwest } & -0.460 & 0.073 & 2.27 & -0.323 & 0.115 & 1.64 \\
\hline & $(0.434)$ & $(0.348)$ & & $(0.420)$ & $(0.342)$ & \\
\hline \multirow[t]{2}{*}{ MERCOSUR_memb } & $0.705^{*}$ & $1.113^{*}$ & $5.85^{* *}$ & $0.672 *$ & $1.088^{*}$ & $6.45^{* *}$ \\
\hline & $(0.163)$ & $(0.173)$ & & $(0.160)$ & $(0.172)$ & \\
\hline \multirow[t]{2}{*}{ BRZ_north } & $-1.069^{*}$ & $-0.901 *$ & 0.30 & $-0.933 * *$ & $-0.776^{* *}$ & 0.23 \\
\hline & $(0.405)$ & $(0.301)$ & & $(0.416)$ & $(0.311)$ & \\
\hline \multirow[t]{2}{*}{ BRZ_south } & $-0.773 * *$ & $-0.623 * *$ & 1.30 & $-0.707 * *$ & $-0.555^{* *}$ & 1.31 \\
\hline & $(0.326)$ & $(0.289)$ & & $(0.319)$ & $(0.281)$ & \\
\hline \multirow{2}{*}{ BRZ_northeast } & $-1.583^{*}$ & $-1.746^{*}$ & 1.23 & $-1.443^{*}$ & $-1.640^{*}$ & 1.66 \\
\hline & $(0.329)$ & $(0.289)$ & & $(0.324)$ & $(0.281)$ & \\
\hline \multirow[t]{2}{*}{ BRZ_southeast } & -0.434 & -0.384 & 0.24 & -0.376 & -0.323 & 0.27 \\
\hline & $(0.311)$ & $(0.286)$ & & $(0.305)$ & $(0.279)$ & \\
\hline \multirow[t]{2}{*}{ BRZ_centerwest } & $-2.147^{*}$ & $-1.611 *$ & $5.19 * *$ & $-1.953 *$ & $-1.495^{*}$ & $3.31 * *$ \\
\hline & $(0.368)$ & $(0.308)$ & & $(0.369)$ & $(0.302)$ & \\
\hline Observations & 78580 & 78580 & & 78580 & 78580 & \\
\hline Importer fixed effects & Yes & Yes & & Yes & Yes & \\
\hline Exporter fixed effects & Yes & Yes & & Yes & Yes & \\
\hline Time fixed effects & Yes & Yes & & Yes & Yes & \\
\hline-2 log pseudo-likelihood & 5981132 & 5981132 & & 5860211 & 5860211 & \\
\hline Vuong $(z)$ & & & & - & - & \\
\hline $\mathrm{AIC}$ & 5981772 & 5981772 & & 5860859 & 5860859 & \\
\hline $\mathrm{BIC}$ & 5984739 & 5984739 & & 4978119 & 4978119 & \\
\hline
\end{tabular}

${ }^{a}$ Dependent variable is scaled by $10^{6}$. Robust standard errors in parentheses: All inferences are based on a Huber-White sandwich estimate of variance. $* * *$ Significant at $10 \% ; * *$ significant at $5 \%$; ${ }^{*}$ significant at $1 \%$. Only results for interest variables are given.

Brazil's integration with the rest of world (non-member countries) is significantly negative for all regions except for the South-Eastern regions whose coefficient is not significantly different from zero. So the Brazilian regions are little integrated into world trade. The change in the coefficients shows no evidence of a trade diversion effect. Exceptionally, however, the Center-West has significantly increased its trade with non-member countries. This result calls for further study. The region became more specialized in exportable agricultural goods over the period, which could be a plausible explanation for the increase in trade with third countries and could also explain why the region trades very little with MERCOSUR members whose agricultural specialization is in similar products (soya, beef, etc.)

\section{CONCLUSION}

The purpose of this paper was to consider the effects of MERCOSUR on the trade of Brazilian states by highlighting three contradictory effects: a trade creation effect with MERCOSUR countries and an expected diversion effect with other countries, but also a preference erosion effect on interstate trade. We confirm that Brazil "prefers" to trade with itself and with MERCOSUR countries rather than trading with the rest of the world. In spite of its trade openness, Brazil remains poorly integrated compared with the other countries in the world. However, MERCOSUR has had a significant trade creation effect without affecting either interstate trade or trade with the rest of the world. Although trade with MERCOSUR decreased in the late 1990s, this was mainly due to the economic crisis and monetary adjustments rather than a lack of integration. Nevertheless, MERCOSUR's positive effects are unevenly spread across the different Brazilian regions. 
A lack of updated statistics on interstate trade means that the number of years considered in this article is unfortunately too short to see how MERCOSUR's impact on trade develops over a longer period.

The updating of data would mean that we could analyze the effects of MERCOSUR over a longer period. We would then expect the effects to dwindle over time. The analysis also needs extending in a number of directions. We need to improve the identification of trade barriers between states caused mainly by poor infrastructures and the particularity of the Brazilian tax system. And an analysis should be conducted of changes in states' specialization patterns in order to point up the paradoxical development of high-tech industries in Manaus, the recent industrialization of the east coast and the displacement of agriculture from the south to the center. 


\section{References}

Anderson, J.E., Van Wincoop, E. (2003). Gravity with Gravitas: A Solution to the Border Puzzle. The American Economic Review 93(1): 170-192

Baldwin, R., Taglioni, D. (2006). Gravity for Dummies and Dummies for Gravity Equations. NBER Working Paper No 12516

Balistreri, E.J., Hillberry, R.H. (2007). Structural estimation and the border puzzle. Journal of International Economics 72(2): 451-463

Brami, C.A., Siroën, J.M. (2007). Mondialisation et politique fiscale au Brésil. Les Etudes du CERI No 140

Burger, M.J., van Oort, F., Linders, G.J.M. (2009). On the Specification of the Gravity Model of Trade: Zeros, Excess Zeros and Zero-inflated Estimation. Spatial Economic Analysis 4(2): 167-190

Chen, N. (2004). Intra-national versus international trade in the European Union: why do national borders matter?. Journal of International Economics, 63(1): 93-118

COTEPE/ CONFAZ (2000). Balança Comercial Interestadual de 1997. Comissao Tecnica Permanente do ICMS do Confaz

Daumal, M., Zignago, S. (2010). Measure and determinants of border effects of Brazilian states. Papers in Regional Science, 89(4): 735-758

Deardorff, A.V. (1998). Determinants of Bilateral Trade. Does Gravity Work in a Neoclassical World?. In: Frankel JA (ed) The regionalization of the world economy, University of Chicago Press, Chicago

Feenstra, R.C. (2004). Advanced International Trade. Theory and Evidence. Princeton University Press, Princeton

Frankel, J. (1997). Regional Trading Blocs in the World Economic System. Institute for International Economics, Washington DC

Freund, C. (2009). The Trade Response to Global Downturns: Historical Evidence. Policy Research Working Paper No. 5015, Washington, DC: World Bank.

Greene, W.H. (1994). Accounting for Excess Zeros and Sample Selection in Poisson and Negative Binomial Models. Working Paper 94-10, New York University Stern, School of Business.

Helliwell, J.F. (1998). How Much Do National Borders Matter?. Washington, DC: Brookings Institution Press

Hummels, D., Ishii, J., Yi, K.M. (2001). The Nature and Growth of Vertical Specialization in World Trade. Journal of International Economics, 54(1): 75-96

Hidalgo, A.B., Vergolino, J.R. (1998). O Nordeste e o Comércio Inter-regional e Internacional: Um teste dos Impactos por Meio do Modelo Gravitacional. Brazilian Journal of Applied Economics, 2(4): 707-725

Lambert, D. (1992). Zero-inflated Poisson regression with an application to defects in manufacturing. Technometrics, 34: 1-14

Leusin, Jr.S., de Azevedo, A.F.Z. (2009). O efeito frontera das regiões Brasilieiras: Uma aplicação do modelo. Revista de Economia Contemporânea, 13(2): 229-258 
Long, J.S. (1997). Regression Models for Categorical and Limited Dependent Variables. Thousand Oaks, CA: Sage Press

Magee, C. (2008). New Measures of Trade Creation and Trade Diversion. Journal of International Economics, 75(2): 349-362

McCallum, J.T. (1995). National Borders Matter: Canada-U.S. Regional Trade Patterns. American Economic Review, 85(3): 615-623

Okubo, T. (2004). The border effect in the Japanese market: A Gravity Model analysis. Journal of the Japanese and International Economies, 18(1): 1-11

Paz, L.S., Neto, A.A. de Mello Franco (2003). Brazilian Border and Mercosul Integration Effects: an Exploratory Assessment Using the Gravity Model. Associação Nacional dos Centros de Pósgraduação em Economia, ANPEC

Poncet, S. (2003). Measuring Chinese domestic and international integration?. China Economic Review, 14(1): 1-22

Poncet, S. (2005). A Fragmented China: Measure and Determinants of Chinese Domestic Market Disintegration. Review of International Economics, 13(3): 409-430

Rauch, J.E. (1999). Networks versus markets in international trade. Journal of International Economics, 48(1): 7-35

SEFAZ-PE (1993). Operacoes Interestaduais Tributadas pelo ICMS no Brazil -1991. Recife : Secretaria da Fazenda de Pernambuco

Santos Silva, J., Tenreyro, S. (2006). The Log of Gravity. Review of Economics and Statistics, 88(4): 641-658

Silva, O., Almeida, F., Oliveira, B. (2007). Comércio internacional "x" intranacional no Brasil: medindo o efeitofronteira. Nova Economia, 17(3): 427-439

Vasconcelos, J. (2001a). Matriz do Fluxo de comercio Interestadual de bense serviços no Brasil - 1998. Working Paper 783, IPEA

Vasconcelos, J. (2001b). Matriz do Fluxo de comercio Interestadual de bense serviços no Brasil - 1999. Working Paper 817, IPEA

Vuong, Q.H. (1989). Likelihood ratio tests for model selection and non-nested hypotheses. Econometrica, 57: $307-$ 333

Yi, K.M. (2003). Can Vertical Specialization Explain the Growth of World Trade?. Journal of Political Economy, 111(1): 52-102

Yi, K.M. (2009). The Collapse of Global Trade: The Role of Vertical Specialisation. In: Baldwin, R. \& Evenett, S. (eds), The Collapse of Global Trade, Murky Protectionism, and the Crisis: Recommendations for the G20, VoxEU.org Publication

Wolf, H.C. (2000). Intranational Home Bias in Trade. The Review of Economics and Statistics, 82(4): 555-563 
Annex

1. Brazilian Regional Map and States

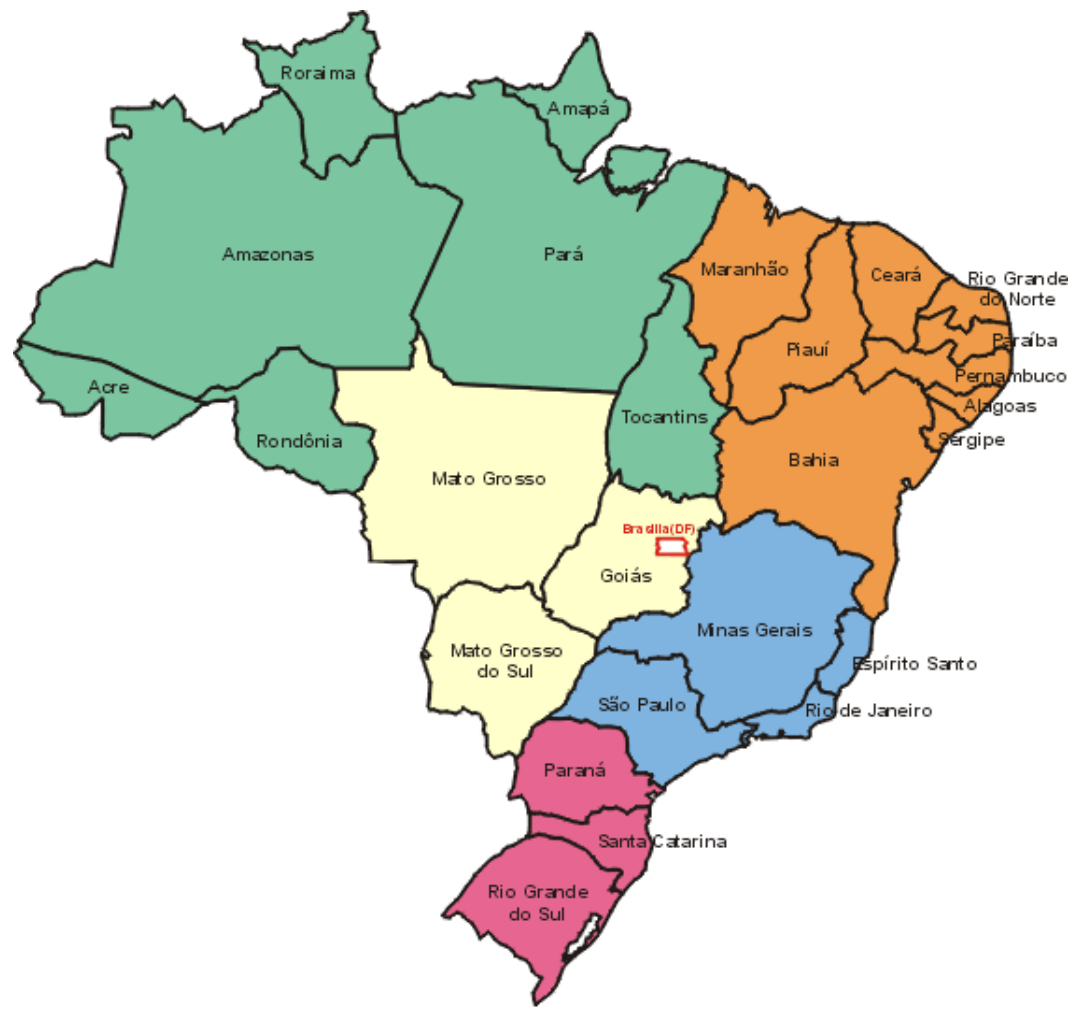

$\square$ Região Norte

$\square$ Região Nordeste

$\square$ Região Centro-Oeste

$\square$ Região Sudeste

$\square$ Região sul

2. List of Countries 


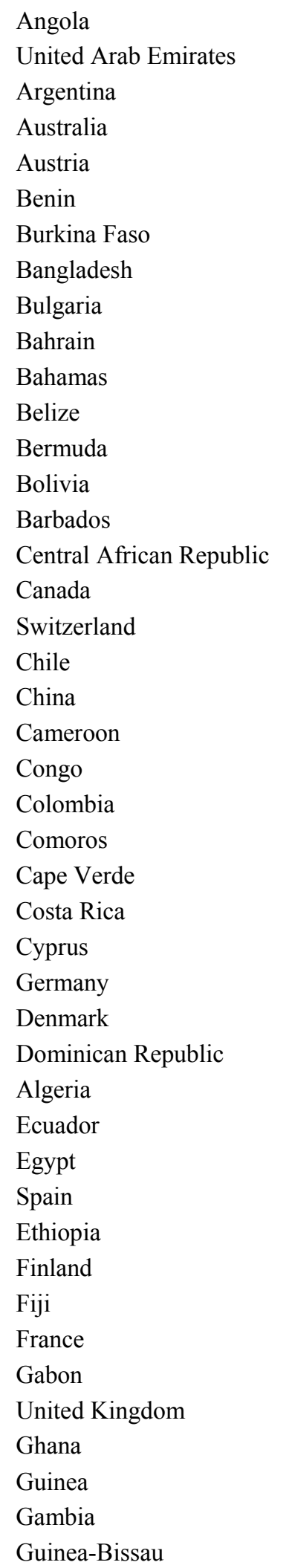

\begin{tabular}{|c|c|}
\hline AGO & Jordan \\
\hline ARE & Japan \\
\hline ARG & Korea, Republic (Sud), Republic Of \\
\hline AUS & Kuwait \\
\hline AUT & Lebanon \\
\hline $\mathrm{BEN}$ & Liberia \\
\hline BFA & Libya \\
\hline BGD & Sri Lanka \\
\hline BGR & Morocco \\
\hline BHR & Madagascar \\
\hline BHS & Mexico \\
\hline BLZ & Mali \\
\hline BMU & Malta \\
\hline BOL & Mozambique \\
\hline $\mathrm{BRB}$ & Mauritania \\
\hline CAF & Mauritius \\
\hline CAN & Malawi \\
\hline $\mathrm{CHE}$ & Malaysia \\
\hline CHL & Niger \\
\hline $\mathrm{CHN}$ & Nigeria \\
\hline CMR & Nicaragua \\
\hline $\mathrm{COG}$ & Netherlands \\
\hline $\mathrm{COL}$ & Norway \\
\hline $\mathrm{COM}$ & Nepal \\
\hline $\mathrm{CPV}$ & New Zealand \\
\hline CRI & Pakistan \\
\hline CYP & Panama \\
\hline DEU & Peru \\
\hline DNK & Philippines \\
\hline DOM & Poland \\
\hline DZA & Portugal \\
\hline $\mathrm{ECU}$ & Paraguay \\
\hline EGY & Qatar \\
\hline ESP & Romania \\
\hline ETH & Rwanda \\
\hline FIN & Saudi Arabia \\
\hline FJI & Sudan \\
\hline FRA & Senegal \\
\hline GAB & Singapore \\
\hline GBR & Sierra Leone \\
\hline GHA & El Salvador \\
\hline GIN & Suriname \\
\hline GMB & Sweden \\
\hline GNB & Syrian Arab Republic \\
\hline
\end{tabular}

JOR

JPN

KOR

KWT

LBN

LBR

LBY

LKA

MAR

MDG

MEX

MLI

MLT

MOZ

MRT

MUS

MWI

MYS

NER

NGA

NIC

NLD

NOR

NPL

NZL

PAK

PAN

PER

PHL

POL

PRT

PRY

QAT

ROM

RWA

SAU

SDN

SEN

SGP

SLE

SLV

SUR

SWE

SYR 
Greece

Grenada

Guatemala

Guyana

Hong Kong

Honduras

Haiti

Hungary

Indonesia

India

Ireland

Iceland

Israel

Italy

Jamaica

$\begin{array}{ll}\text { GRC } & \text { Chad } \\ \text { GRD } & \text { Togo } \\ \text { GTM } & \text { Thailand } \\ \text { GUY } & \text { Trinidad And Tobago } \\ \text { HKG } & \text { Tunisia } \\ \text { HND } & \text { Turkey } \\ \text { HTI } & \text { Tanzania, United Republic Of } \\ \text { HUN } & \text { Uganda } \\ \text { IDN } & \text { Uruguay } \\ \text { IND } & \text { United States of America } \\ \text { IRL } & \text { Venezuela } \\ \text { ISL } & \text { Vietnam } \\ \text { ISR } & \text { Yemen } \\ \text { ITA } & \text { Zambia } \\ \text { JAM } & \text { Zimbabwe }\end{array}$

TCD

TGO

THA

TTO

TUN

TUR

TZA

UGA

URY

USA

VEN

VNM

YEM

ZMB

ZWE 